\title{
PERAN TINGKAT SUKU BUNGA, CAPITAL ADEQUACY RATIO, NET PERFORMING LOAN, RETURN ON ASSET DAN LOAN TO DEPOSIT RATIO TERHADAP PENYALURAN KREDIT USAHA MIKRO KECIL DAN MENENGAH (STUDI PADA BANK UMUM NASIONAL DI WILAYAH SURAKARTA)
}

\author{
Aris Tri Haryanto \\ Sekolah Tinggi Ilmu Ekonomi AUB Surakarta \\ e-mail : arisharyanto26@yahoo.co.id \\ Septiana Novita Dewi \\ Sekolah Tinggi Ilmu Ekonomi AUB Surakarta \\ e-mail : septianadewi25@yahoo.co.id
}

\begin{abstract}
This study aims to determine the bank interest rates, Capital Adequacy Ratio, Non Performing loans, Return On Assets and Loan to Deposit Ratio significantly influence the amount of loans channeled by banks. The analysis technique used by regression, the samples in this study include: Banking companies in the Surakarta region that have been registered with Bank Indonesia that has been Go Public. National commercial banks that have complete data needed in this research variable. The results of this study indicate that the interest rates have a positive and significant effect, the variable Capital Adequacy Ratio (CAR) has a negative but not significant effect, the variable Net Performing Loan (NPL) has a negative and significant effect. The variable Return on Assets (ROA) has a positive but not significant effect, the variable Loan to Deposit Ratio (LDR) has a positive and significant effect on lending to MSMEs.
\end{abstract}

\begin{abstract}
ABSTRAK
Penelitian ini bertujuan untuk mengetahui tingkat suku bunga bank, Capital Adequacy Ratio, Non Performing loan, Return On Asset dan Loan to Deposit Ratio berpengaruh signifikan terhadap jumlah kredit yang disalurkan oleh bank. Tehnik analisis yang digunakan dengan regresi, sampel dalam penelitian ini meliputi :Perusahaan perbankan di wilayah Surakarta yang telah terdaftar di Bank Indonesia yang sudah Go Public., Bank umum nasional yang memiliki kelengkapan data yang dibutuhkan dalam variabel penelitian ini. Hasil penelitian ini menunjukkan ariabel Tingkat Suku Bunga berpengaruh positif dan signifikan, variabel Capital Adequacy Ratio (CAR) berpengaruh negatif tetapi tidak signifikan, variabel $\mathrm{Net}$ Performing Loan (NPL) berpengaruh negatif dan signifikan. variabel Return On Asset (ROA) berpengaruh positif tetapi tidak signifikan, variabel Loan to Deposit Ratio (LDR) berpengaruh positif dan signifikan terhadap penyaluran kredit pada UMKM.
\end{abstract}

Kata Kunci : Tingkat suku bunga bank, Capital Adequacy Ratio, Non Performing loan, Return On Asset dan Loan to Deposit Ratio dan Penyaluran Kredit. 


\section{PENDAHULUAN}

Usaha Mikro kecil Menengah (UMKM) merupakan sektor usaha yang memiliki peran dalam pertumbuhan dan perkembangan ekonomi di Indonesia, Peran serta tersebut dapat dilihat dari jumlah unit industrinya dimana hinggs tahun 2012 mencapai 99,9\% menguasai unit usaha di Indonesia, kontribusinya dalam penyerapan tenaga kerja, serta kontribusinya dalam pembentukan PDB di Indonesia ynag mencapai $57,48 \%$ dari total PDB Indonesia. Dari peranan tersebut pemerintah mengharapkan pertumbuhan UMKM yang terus meningkat.

Modal merupakan hal yang sangat penting bagi para pengusaha yang ingin memulai dan juga mengembangkan usaha akan tetapi Modal masih menjadi kendala bagi sebagian pelaku Usaha Mikro Kecil dan Menengah (UMKM). Walaupun pada umumnya permodalan awal itu biasanya berasal dari diri sendiri dan sumber sumber informal maupun investasi,namun permodal yang berasal dari diri dan sumber informal maupun investasi tersebut dirasa kurang untuk mencukupi kebutuhan yang diperlukan. Oleh karena itu akses permodalan formal seperti bank merupakan solusi paling efektif untuk mengatasi masalah permodalan tersebut.

Indonesia telah mengalami perkembangan ekonomi yang sangat cepat. Perkembangan ekonomi tidak lepas dari peran bank sebagai lembaga keuangan yang mengatur, menghimpun, dan menyalurkan dana yang telah dipercayakan oleh masyarakat dalam bentuk simpanan. Bank sebagai lembaga keuangan memiliki peranan yang sangat penting sebagai perantara antara pihak yang kelebihan dana dengan pihak yang memerlukan dana. Dana tersebut disalurkan oleh bank dalam bentuk kredit ataupun dalam bentuk lainnya. Akan tetapi perekonomian Indonesia yang saat ini terjadi terus melambat bisa terselamatkan. Usaha Kecil Mikro Menengah (UMKM) bisa diandalkan menjadi dewa penyelamat.

Berdasarkan pasal 1 Undang Undang No. 10 Tahun 1998 tentang perubahan Undang - Undang No. 7 Tahun 1992 tentang Perbankan, Bank didefinisikan sebagai berikut : Bank adalah badan usaha yang menghimpun dari masyarakat dalam bentuk simpanan dan menyalurkan kepada masyarakat dalam rangka meningkatkan taraf hidup rakyat banyak. Menurut SAK no. 31 tahun 2009 (revisi tahun 2000), Bank adalah lembaga yang berperan sebagai perantara keuangan (financial intermediary) antara pihak yang memiliki dana dan pihak yang memerlukan dana, serta sebagai lembaga yang berfungsi memperlancar lalu lintas pembayaran. Falsafah yang mendasari kegiatan usaha bank adalah kepercayaan masyarakat. Hal tersebut tampak dalam kegiatan pokok bank yang menerima simpanan dari masyarakat dalam bentuk giro, tabungan, serta deposito berjangka dan memberikan kredit kepada pihak yang memerlukan dana. Menurut PBI No.10/19/2008 menjelaskan, "Bank adalah Bank Umum sebagaimana dimaksud dalam Undang-Undang Nomor 7 Tahun 1992 tentang Perbankan sebagaimana telah diubah dengan Undang Undang Nomor 10 Tahun 1998, termasuk kantor cabang bank asing, yang melakukan kegiatan usaha secara konvensional".

Permodalan menggunakan akses perbankan tidaklah selalu menjadi 
pemecah kebuntuan atau sebagai solusi yang tepat untuk mengatasi permodalan tetap saja masih ada permasalahan yang muncul, Selain syarat pengajuan kredit, besaran bunga yang di patok bank juga dinilai terlalu besar dalam memberikan kredit biasanya bank memberikan syaratsyarat kepada para nasabah yang ingin mengajukan kredit. Penyaluran kredit bank memiliki faktor-faktor dari sisi internal perbankan yang mampu mempengaruhi penyaluran kredit,antar lain Non performing Loan (NPL), Suku bunga Bank, Capital Adequacy Ratio (CAR), Loan to deposit Ratio (LDR), dan juga Return On Asset (ROA).

Menurut Prabowo (2014:4), "NPL merupakan rasio yang di gunakan untuk mengukur kemampuan bank dalam mengcover risiko kegagalan pengembalian kredit oleh debitur". Pembayaran kredit oleh debitur merupakan suatu keharusan agar kegiatan opersional bank dapat berjalan dengan lancar. Jika pada suatu bank banyak terjadi penunggakan pembayaran kredit oleh debitur maka bank tidak bisa mendapatkan kembali modal yang telah dikeluarkan, sehingga dapat mempengaruhi tingkat kesehatan bank dan dapat berefek pada penurunan tingkat kepercayaan masyarakat. Menurut Peraturan Bank Indonesia Nomor 6/10/PBI/2004 tanggal 12 April 2004 tentang Sistem Penilaian Tingkat Kesehatan Bank Umum, semakin tinggi nilai NPL (diatas 5\%) maka bank tersebut tidak sehat. Namun pada kenyataannya, menurut rasio NPL BRI rata-rata di atas $5 \%$, namun jumlah plafond penyaluran KUR BRI dari tahun ke tahun tetap tinggi dan mengalami peningkatan.

Bank dalam memberikan kredit kepada masyarakat juga dipengaruhi oleh besarnya suku bunga pinjaman. Bunga pinjaman merupakan imbal jasa atas penyaluran pinjaman dana yang disalurkan bank dalam bentuk kredit. Apabila suku bunga kredit bank tinggi maka bank akan meningkatkan jumlah kreditnya, karena bank menginginkan keuntungan yang besar.

Loan to Deposit Ratio (LDR) merupakan rasio yang menunjukkan kemampuan suatu bank dalam menyediakan dana kepada debiturnya dengan modal yang dimiliki oleh bank maupun dana yang dapat dikumpulkan dari masyarakat. Loan to Deposit Ratio menunjukkan kemampuan bank didalam menyediakan dana kepada debiturnya dengan modal yang dimiliki oleh bank maupun dana yang dikumpulkan dari masyarakat (Achmad dan Kusuno, 2003).

Capital Adequacy Ratio merupakan permodalan bagi semua bank yang digunakan sebagai penyangga kegiatan operasional sebuah bank maupun penyangga terhadap kemungkinan terjadinya kerugian. Semakin tinggi CAR semakin baik kondisi sebuah bank karena modal yang ada dapat disalurkan kembali untuk dilakukannya penyaluran kredit untuk mendapatkan pendapatan perusahaan perbankan (Hamonangan dan Siregar, 2009).

ROA (Return On Asset) adalah rasio keuntungan bersih pajak yang juga berarti suatu ukuran untuk menilai seberapa besar tingkat pengembalian dari aset yang dimiliki perusahaan. (Bambang R, 1997). Return On Assets (ROA) yang signifikan menunjukan bahwa dari total aktiva yang dipergunakan untuk operasi perusahaan mampu memberikan laba bagi perusahaan. Sebaliknya jika ROA negatif 
menunjukan toal aktiva yang dipergunakan tidak memberikan keuntungan/rugi.

Penelitian terdahulu oleh Adelya dan Jafar (2009) meneliti pengaruh dana pihak ketiga terhadap penyaluran kredit. Hasil dari penelitian yang telah dilakukan oleh Adelya dan Jafar tersebut dana pihak ketiga berpengaruh signifikan dan signifikan terhadap penyaluran kredit. Penelitian yang dilakukan Francisca dan Siregar (2009) meneliti faktor internal bank yang berpengaruh pada volume kredit pada bank go public di Indonesia. Hasil dari penelititan tersebut adalah dana pihak ketiga dan ROA berpengaruh signifikan dan signifikan terhadap volume kredit. Sedangkan CAR, NPL berpengaruh signifikan dan negatif namun tidak signifikan terhadap volume kredit. Keempat variabel tersebut secara simultan berpengaruh signifikan dan signifikan terhadap volume kredit.

Putra (2014) melakukan penelitian Pengaruh LDR, BI Rate, CAR, NPL Terhadap Penyaluran Kredit UMKM di Bank Umum Provinsi Bali Periode 2004.I2013.IV, hasil dari penelitian ini Ditemukan hasil bahwa LDR berpengaruh positif dan signifikan, BI rate berpengaruh negatif dan signifikan, CAR serta Non Performing Loan berpengaruh negatif dan signifikan terhadap jumlah kredit UMKM yang disalurkan bank umum.

Faktor yang membedakan dengan penelitian terdahulu adalah variabel Suku bunga kredit dan Return On Asset yang dimasukkan dalam penelitian menggantikan variabel $\mathrm{BI}$ rate. selain faktor internal perusahaan yang berpengaruh terhadap penyaluran kredit pada UMKM oleh perusahaan perbankkan. Faktor internal perusahaan kembali diteliti untuk mengukur konsistensi hasil dari penelitian sebelumnya yang hasilnya dapat dibandingkan atau bahkan sebagai penguat hasil penelititan sebelumnya. Suku Bunga kredit sangat memiliki peran penting dalam peyaluran kredit terhadap masyarakat karena suku bunga kredit adalah salah satu faktor yang berpengaruh terhadap kelangsungan suatu perbankan dan juga penyaluran kredit pada UMKM bank dan Return On Asset adalah rasio untuk mengukur tingkat optimalisasi aktiva yang dimiliki untuk menghasilkan keuntungan.

1. Suku Bunga Bank terhadap penyaluran kredit pada UMKM

Bunga pinjaman merupakan imbal jasa atas penyaluran pinjaman dana yang disalurkan bank dalam bentuk kredit. Menurut Kasmir (2008:37), bunga bank berdasarkan prinsip konvensional dapat diartikan sebagai balas jasa yang diberikan oleh bank kepada nasabah yang membeli atau menjual produknya. Bank dalam memberikan kredit kepada masyarakat juga dipengaruhi oleh besarnya tingkat suku bunga pinjaman. Apabila suku bunga kredit bank tinggi maka bank akan meningkatkan jumlah kreditnya, karena bank menginginkan keuntungan yang besar. Sebaliknya, masyarakat melakukan investasi berupa pembelian asset atau membuka kesempatan usaha guna memperoleh laba tergantung/merupakan fungsi dari tingkat bunga. Makin tinggi tingkat bunga, keinginan untuk melakukan investasi semakin kecil. Alasannya, seorang pengusaha akan menambah pengeluaran investasinya apabila keuntungan yang diharapkan dari investasi lebih besar dari tingkat bunga yang harus dia bayar untuk dana 
investasi tersebut yang merupakan ongkos untuk penggunaan dana (cost of capital). Makin rendah tingkat bunga, maka pengusaha akan lebih terdorong untuk melakukan investasi, sebab biaya penggunaan dana juga makin kecil (Nopirin, 1992:71). Berdasarkan penelitian Kaunang (2013), diketahui bahwa Suku Bunga memiliki pengaruh secara signifikan terhadap penyaluran Kredit.

$\mathrm{H}_{1}=$ Tingkat Suku Bunga Bank berpengaruh signifikan terhadap penyaluran kredit pada UMKM

2. Capital Adequacy Ratio Terhadap Penyaluran kredit pada UMKM

Capital Adequacy Ratio terkait dengan kecukupan modal sendiri bank selain sumber modal dari luar seperti dana masyarakat dan pinjaman (utang) terhadap aktiva bank yang mengandung risiko. Capital Adequacy Ratio termasuk faktor internal bank yang syaratnya harus dipenuhi oleh setiap bank. Besarnya kecukupan modal bank di seluruh bank yang ada di Indonesia telah ditentukan oleh Bank Indonesia sebesar 8\%. Kecukupan modal yang tinggi dan memadai akan meningkatkan volume kredit perbankan (Fransisca dan Siregar, 2009). Semakin kecukupan modal tinggi maka kemampuan bank untuk menyalurkan kredit kepada masyarakat semakin besar. Berdasarkan Putra (2014) bahwa Capital Adequacy Ratio (CAR) berpengaruh secara signifikan terhadap Volume Kredit yang disalurkan.

$\mathrm{H}_{2}=$ Capital Adequacy Ratio berpengaruh Signifikan terhadap penyaluran kredit pada UMKM

3. Non performing loan Terhadap Penyaluran kredit pada UMKM
Non performing loan atau

kredit bermasalah adalah banyaknya pinjaman yang mengalami kesulitan dalam pelunasannya. Ini diakibatkan karena kesengajaan debitur atau karena sesuatu diluar kendali debitur. Non performing loan merupakan salah satu faktor internal bank yang penting dalam penyaluran kredit. Non performing loan juga biasa digunakan untuk mengukur kualitas asset pada analisis CAMELS. Semakin tinggi tingkat kredit macet maka semakin buruk pula kualitas aset yang dimiliki bank. Namun demikian, apabila semakin rendah tingkat kredit macet yang dialami suatu bank, maka jumlah kredit yang disalurkan akan semakin besar. Kredit bermasalah yang tinggi dapat menimbulkan keengganan bank untuk menyalurkan kredit karena harus membentuk cadangan penghapusan yang besar. Semakin besar kredit macet atau kredit yang bermasalah yang dialami perusahaan perbankan, maka keadaan tersebut menimbulkan keengganan bank untuk menyalurkan kredit kepada masyarakat sehingga jumlah kredit yang disalurkan pun akan menurun. Berdasarkan penelitian Penelitian Putra (2014) bahwa Non Performing Loan (NPL) berpengaruh secara signifikan terhadap Volume Kredit yang disalurkan.

$\mathrm{H}_{3}=$ Non Performing Loan
berpengaruh signifikan terhadap
penyaluran kredit pada UMKM

4. Return On Assets Terhadap Penyaluran kredit pada UMKM

Return On Assets adalah perbandingan antara pendapatan dengan total aset yang dimiliki bank. Return on assets merefleksikan seberapa besar penggunaan aset yang digunakan untuk 
menghasilkan pendapatan. Semakin besar ROA maka semakin optimal pula penggunaan aktiva yang dimiliki bank untuk menghasilkan pendapatan. Return On Assets termasuk faktor internal bank yang juga biasa digunakan untuk mengukur faktor profitabilitas perusahaan perbankan. Menurut Dendawijaya (2005) bahwa kegiatan perkreditan yang dilakukan bank mencapai 70\%-80\% dari kegiatan usaha bank. Hal tersebut membuktikan bahwa mayoritas kegiatan usaha bank adalah penyaluran kredit. Semakin tinggi ROA maka membuktikan bahwa semakin optimal penggunaan aktiva perusahaan untuk memperoleh pendapatan maka berarti kegiatan kredit oleh bank telah dioptimalkan untuk mendapatkan pendapatan. Berdasarkan penelitian Ayu D. A, dkk (2011) bahwa Return On Assets (ROA) berpengaruh secara signifikan terhadap Volume Kredit yang disalurkan.

$\mathrm{H}_{4}=$ Return On Assets berpengaruh signifikan terhadap penyaluran kredit pada UMKM

5. Loan to deposit ratio Terhadap penyaluran kredit pada UMKM

LDR dapat dijadikan tolok ukur kinerja lembaga intermediasi yaitu lembaga yang menghubungkan antara pihak yang kelebihan dana ( unit surplus of funds ) dengan pihak yang membutuhkan dana ( unit deficit of funds ). Loan to deposit ratio adalah rasio yang mengukur kemampuan kredit yang telah disalurkan guna membayar semua dana masyarakat serta modal sendiri. Semakin tinggi Loan to deposit ratio maka kemampuan kredit yang telah disalurkan oleh bank juga semakin tinggi guna membayar kewajiban jangka pendeknya seperti membayar kembali pencairan dana deposan dari kreditur, bunga yang seharusnya diberikan, dan memenuhi permintaan kredit oleh debitur. Meydianawathi (2007) mengatakan bahwa selain dana yang tersedia (DPK), perilaku penawaran kredit juga dipengaruhi oleh pandangan bank atas terhadap prospek usaha debitor dan kondisi perbankan itu sendiri, seperti Permodalan (CAR), jumlah kredit macet (NPL), dan loan to deposit ratio (LDR). Dasar teori tersebut menunjukkan perilaku penyaluran kredit dipengaruhi rasio Loan to Deposit Ratio. Menurut anjuran Bank Indonesia, LDR yang aman adalah pada kisaran 78\%-100\%. Apabila suatu bank mampunyai tingkat LDR lebih dari $100 \%$, maka harus menambah GWM sebesar $0,2 \%$ untuk setiap peningkatan LDR sebesar $1 \%$. Untuk memenuhi anjuran Bank Indonesia tersebut, maka bank berusaha untuk menaikkan rasio LDR selama rasio LDR bank tersebut belum memenuhi anjuran BI, maka penyaluran kredit pada UMKM juga akan semakin besar tiap tahunnya. Sebaliknya apabila rasio LDR bank tersebut sudah terlalu besar, maka perusahaan perbankan berusaha menurunkan LDR, maka diikuti pula penyaluran kredit pada UMKM yang semakin menurun. Apabila loan to deposit ratio ingin ditingkatkan sesuai anjuran bank sentral, maka jumlah kredit yang disalurkan pun meningkat namun apabila rasio LDR turun maka hal tersebut menyebabkan jumlah kredit yang menurun. Berdasarkan penelitian Putra (2014) bahwa Loan to Deposit Ratio (LDR) berpengaruh secara 
signifikan terhadap Volume Kredit yang disalurkan.

$\mathrm{H}_{5}=$ Loan to deposit ratio berpengaruh signifikan terhadap penyaluran kredit pada UMKM
Dalam penelitian ini menguji pengaruh signifikan antara Suku Bunga Kredit Bank, Net Performing Loan, Capital Adequacy Ratio, Return On Assets, dan Loan to Deposit Ratio terhadap penyaluran kredit UMKM.

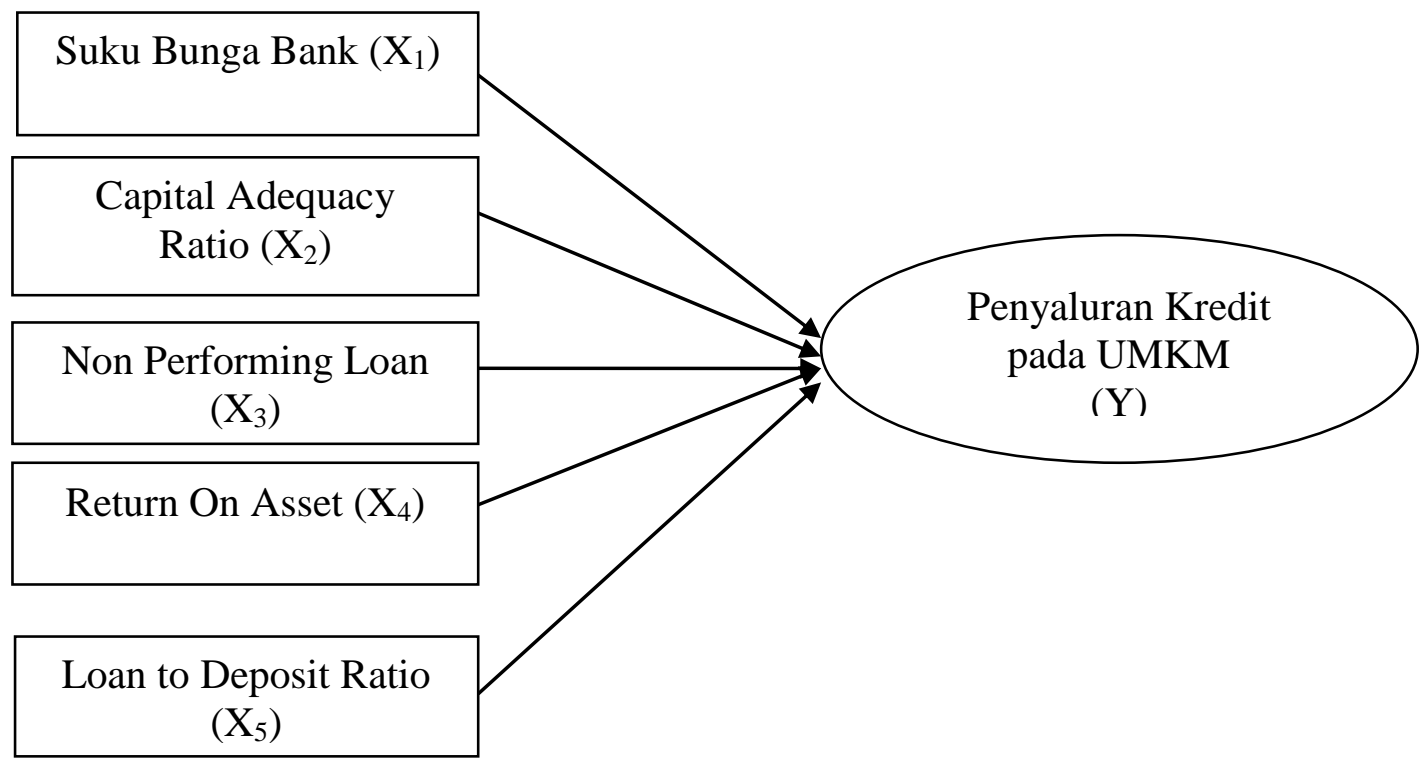

Gambar1. Kerangka pemikiran

\section{METODE}

Populasi yang digunakan dalam penelitian ini adalah seluruh Bank Umum Nasional yang sudah Go Publik dan terdaftar di BEI periode 2011-2014. Pengambilan sampel dalam penelitian ini dilakukan dengan menggunakan metode purposive sampling, karena mengambil sampel dari populasi berdasarkan suatu kriteria tertentu. Kriteria bank umum nasional yang menjadi sampel dalam penelitian ini meliputi :

1. Perusahaan perbankan di wilayah Surakarta yang telah terdaftar di Bank Indonesia yang sudah Go Public.

2. Bank umum nasional yang memiliki kelengkapan data yang dibutuhkan dalam variabel penelitian ini, antara lain data mengenai suku bunga, ROA, LDR, NPL, CAR, dan Penyaluran kredit pada UMKM yang terdapat pada laporan tahunan pada periode tahun 2011 hingga 2014

Berdasarkan kriteria tersebut di atas, bank umum nasional yang memenuhi kriteria untuk menjadi sampel adalah sepuluh (10) bank umum nasional yang terdapat di wilayah Surakarta, yaitu BRI, BNI, BTN, BCA, BANK PANIN, BRI, BNP, BANK DANAMON, BANK MEGA, dan BANK SINARMAS . 


\section{Metode Pengumpulan Data}

Jenis data yang digunakan dalam penelitian ini adalah jenis data sekunder. Data sekunder merupakan data yang diperoleh dari pihak lain atau sumber lain yang berkaitan dengan penelitian ini yang sudah diolah dan didapatkan melalui dokumen-dokumen yang telah tersedia.

\section{ANALISIS DAN PEMBAHASAN}

Pada variabel Tingkat Suku Bunga

Bank mempunyai nilai minimum sebesar 4,26 dan nilai maksimum sebesar 20,26. Sementara itu, simpangan baku sebesar 3,93916 masih lebih kecil jika dibandingkan nilai rata-ratanya sebesar 12,8823. Dengan demikian dapat dikatakan bahwa simpangan data pada Tingkat Suku Bunga Bank relatif baik.

Variabel CAR(Capital Adequacy

Ratio) mempunyai nilai minimum sebesar 11,70 dan nilai maksimum sebesar 21,82. Sementara itu, simpangan baku sebesar 2,21957 masih lebih kecil jika dibandingkan nilai rata-ratanya sebesar 16,4553. Dengan demikian dapat dikatakan bahwa simpangan data pada CAR relatif baik.

Variabel NPL(Net Performing Loan) mempunyai nilai minimum 0,20 dan nilai maksimum sebesar 3,12. Sementara itu, simpangan baku sebesar 0,91996 masih lebih kecil jika dibandingkan nilai rata-ratanya sebesar 1,3903. Dengan demikian dapat dikatakan bahwa simpangan data pada NPL relatif baik.
Sumber data pada penelitian ini menggunakan data sekunder berupa laporan keuangan publikasi tahunan bank umum nasional di Indonesia pada tahun 2010 - 2014 di wilayah Surakarta. Data sekunder berasal dari website resmi Bank Indonesia www.bi.go.id dan Annual Report masing-masing perusahaan perbankan.

Variabel Return On Asset (ROA) mempunyai nilai minimum 1,02 dan nilai maksimum sebesar 5,15. Sementara itu, simpangan baku sebesar 1,18953 lebih kecil jika dibandingkan dengan nilai rataratanya sebesar 2,4110. Dengan demikian dapat dikatakan bahwa simpangan data pada ROA relatif baik.

Variabel LDR (Loan to Deposit Ratio) mempunyai nilai minimum sebesar 52,39 dan nilai maksimum sebesar 108,86. Sementara itu, simpangan baku sebesar 12,92159 masih lebih kecil jika dibandingkan dengan nilai rata-ratanya sebesar 82,4748. Dengan demikian dapat dikatakan bahwa simpangan data pada LDR relatif baik.

Variabel Penyaluran Kredit pada UMKM mempunyai nilai minimum sebesar 11,60 dan nilai maksimum sebesar 24,54. Sementara itu, simpangan baku sebesar 3,37938 lebih kecil jika dibandingkan dengan nilai rata-ratanya sebesar 20.8380 . Dengan demikian dapat dikatakan bahwa simpangan data pada Penyaluran kredit pada UMKM relatif baik.

\section{KESIMPULAN DAN SARAN}

1. Variabel Tingkat Suku Bunga $\left(X_{1}\right)$ berpengaruh positif dan signifikan

terhadap penyaluran kredit pada UMKM 
2. Variabel Capital Adequacy Ratio (CAR) $\left(\mathrm{X}_{2}\right)$ berpengaruh negatif tetapi tidak signifikan terhadap penyaluran kredit pada UMKM.

3. Variabel Net Performing Loan (NPL) $\left(\mathrm{X}_{3}\right)$ berpengaruh negatif dan signifikan terhadap penyaluran kredit pada UMKM.

4. Variabel Return On Asset (ROA) $\left(\mathrm{X}_{4}\right)$ berpengaruh positif tetapi tidak signifikan terhadap penyaluran kredit pada UMKM.

5. Variabel Loan to Deposit Ratio (LDR) $\left(\mathrm{X}_{5}\right)$ berpengaruh positif dan signifikan terhadap penyaluran kredit pada UMKM

6. Hasil penelitian dengan menggunakan perhitungan koefisien determinasi $\left(\mathrm{R}^{2}\right)$ menunjukkan bahwa variabel Tingkat Suku Bunga Bank, Capital Adequacy Ratio, Net Performing Loan, Return On Asset dan Loan to Deposit Ratio Terhadap Penyaluran Kredit pada UMKM sebesar 42,5\%. sedangkan sisanya $57,5 \% \quad(100 \%-42,5 \%)$ menunjukkan bahwa Penyaluran kredit pada UMKM dipengaruhi oleh variabel lain diluar penelitian ini.

\section{Saran}

1. Tingkat Suku Bunga berpengaruh positif dan signifikan terhadap penyaluran kredit pada UMKM. Saran yang peneliti beriakn adalah Bank umum dapat memberikan kemudahan dalam pencairan kredit (kredit yang lebih mudah) serta diasuransi dan juga memberikan fasilitas-fasilitas guna menambah minat nasabah untuk mengajukan kredit.

2. Capital Adequacy Ratio ini berpengaruh negatif tetapi tidak signifikan terhadap penyaluran kredit pada UMKM. Saran yang peneliti berikan adalah Capital Adequacy Ratio(CAR) bukan berarti harus diabaiakan karena kecukupan modal sering terganggu seiring pertumbuhan penyaluran kredit yang berlebihan dan banyaknya kredit yang belum dilunasi, yang harus dilakukan bank ialah untuk tetap menjaga atau bahkan meningkatkan kualitas CAR itu sendiri.

3. Net Performing Loan (NPL) berpengaruh negative dan signifikan terhadap penyaluran kredit pada UMKM. Saran yang peneliti berikan adalah jaminan pemberian kredit atas kemampuan dan kesanggupan nasabah debitur untuk melunasi kewajibannya. Sebelum memberikan kredit, bank harus melakukan penilaian yang seksama terhadap watak, kemampuan modal, agunan, dan prospek usaha dari nasabah debitur.

4. Return on Asset (ROA) berpengaruh positif tetapi tidak signifikan terhadap penyaluran kredit pada UMKM. Saran yang peneliti berikan adalah sebaiknya Bank Umum Nasional menjaga tingkat ROA agar tidak mengalami penurunan, dengan melakukan peningkatan volume kredit.

5. Loan to Deposit Ratio berpengaruh positif dan signifikan terhadap penyaluran kredit pada UMKM. Saran yang peneliti berikan adalah menstabilakan dan menjaga rasio LDR di posisi ideal serta memperhatikan kualitas kredit yang disalurkan untuk menghindari terjadinya kualitas kredit yang bermasalah sehingga dapat 
memperoleh keuntungan dari kredit yang disalurkan bank.

\section{Rekomendasi}

Bagi penelitianan selanjutnya diharapkan mengembangkan varibel lain yang berpengaruh terhadap penyaluran kredit pada UMKM misalnya menambah variabel inflasi, dana pihak ketiga dan memperluas populasi dan sampel dengan memperpanjang periode pengamatan sehingga penelitian bisa digeneralisasikan terhadap seluruh perbankan di Indonesia.

\section{DAFTAR PUSTAKA}

Arthesa, Ade dan Handiman, Edia. 2006. "Bank dan Lembaga Keuangan Bukan Bank”, PT. Indeks,

Ayu Fitria D,A, dkk. 2011. Pengaruh Dana Pihak Ketiga (DPK), Capital Adequacy Ratio (CAR), Non Performing Loan (NPL), Return On Assets (ROA) Dan Loan To Deposit Ratio (LDR) Terhadap Volume Kredit Yang Disalurkan Bank Persero. Jurnal ilmiah. Vol 3, No. 2

Bambang Riyanto, 2001. Dasar-Dasar Pembelanjaan Perusahaan, Edisi Keempat, Cetakan Ketujuh, Yogjakarta : BPFE

Binangkit, Yogi Lingga. 2014. Analisis Pengaruh Dana Pihak Ketiga, Non Performing Loan, dan Suku Bunga Pinjaman terhadap Penyaluran Kredit Modal Kerja, Investasi, dan Konsumsi Bank Pembangunan Daerah Periode 2003-2013. Jurnal Ilmiah. Malang: Jurusan Ilmu Ekonomi Fakultas Ekonomi dan Bisnis Universitas Brawijaya

Boediono. 1985. Ekonomi Moneter. Yogyakarta: BPFE Yogyakarta.

Dendawijaya, Lukman, 2005, Manajemen Perbankan, Penerbit Ghalia Indonesia, Jakarta

Ghozali, imam. 2006. Aplikasi analisis multivariate dengan program SPSS. Semarang: badan penerbit universitas diponegoro

Hamonangan, Siregar. 2009. Pengaruh Capital Adequacy Ratio, Debt to Equity Ratio, Non Performing Loan, Operating Ratio, dan Loan to Deposit Ratio terhadap Return on Equity (ROE) Perusahaan Perbankan yang terdaftar di Bursa Efek Indonesia. Jurnal Ilmiah. USU. Sumatera Utara.

Idris, Risti Dwijani. 2012. Pengaruh Suku Bunga Kredit dan Pendapatan Perkapita Terhadap Investasi di Kota Makassar Tahun 2000-2009. Jurnal ilmiah. Makassar: Fakultas Ekonomi Universitas Hasanuddin.

Irsukindro. 1997. Ekonomi Uang dan Bank (Teori dan Pengalaman di Indonesia), Jogjakarta : BPFE.

Kasmir. 2008. Manajemen Perbankan. Edisi Revisi 8. Jakarta: PT. Raja Grafindo Persada. 
Kaunang, Glently. 2013. Tingkat Suku Bunga pinjaman dan Kredit Macet pengaruhnya Terhadap permintaan Kredit UMKM di Indonesia. Jurnal EMBA, Vol. 1,(No. 3).

Kuncoro, Mudrajad. 2002. Metode Kuantitatif (Teori dan Aplikasi Untuk Bisnis dan Ekonomi). Yogyakarta: UPP STIM YKPN Yogyakarta.

Meydianawathi, L. G., 2007, Analisis Perilaku Penawaran Kredit Perbankan Kepada Sektor UMKM di Indonesia, Jurnal ilmiah UII, Yogyakarta.

Muljono, Teguh Pudjo. 1988. Aplikasi Akuntansi Manajemen Dalam Praktek Perbankan. Yogyakarta: BPFE.

Nopirin. 1992. Ekonomi Moneter. Yogjakarta : BPFE.

Parmawati. 2014. Analisis Pengaruh Dana Pihak Ketiga (DPK), Tingkat Suku Bunga Kredit, Capital Adequacy Ratio (CAR), Non Performing Loan (NPL) Dan Return On Assets (ROA)Terhadap Penyaluran Kredit Bank Pada Pt. Bank Tabungan Pensiunan Nasional (BTPN) Tbk Cabang Surakarta. Jurnal Ilmiah. Fakultas Ekonomi Dan Bisnis Universitas Muhammadiyah Surakarta.

Peraturan Bank Indonesia No. 14/22/PBI/2012 tentang Penyaluran Kredit atau Pembiayaan Oleh Bank Umum dan Bantuan Teknis Dalam Rangka Pengembangan Usaha Mikro, Kecil, dan Menengah. Dipublikasikan oleh Bank Indonesia.

Prabowo, Anggono Yuda. 2014. Pengaruh Dana Pihak Ketiga (DPK), Capital Adequacy Ratio (CAR), Non Performing Loan (NPL) Terhadap Penyaluran Kredit Usaha Rakyat (KUR) Studi Kasus Pada PT. Bank Mandiri (Persero) Tbk. Jurnal Ilmiah. Tidak Dipublikasikan. Malang: Jurusan Ilmu Ekonomi Fakultas Ekonomi dan Bisnis Universitas Brawijaya.

Priyatno, Duwi. 2012. Analisis Data dengan SPSS 20. Yogyakarta: Andi.

Putra Grahadika Bagus. 2014 Pengaruh LDR, BI Rate, CAR, NPL Terhadap Penyaluran Kredit UMKM di Bank Umum Provinsi Bali Periode 2004.I-2013.IV. E-Jurnal EP Unud, 3 [12] : 603-612.

Riyadi, Slamet. 2006. “Banking Assets and Liability Management”, LP-FEUI, Jakarta.

Rivai, Veithzal. 2007. Bank and Financial Institute Management . Jakarta: PT. Raja GrafindoPersada.

Rusyamsi Imam, 1999. Asset Liability Management Strategi Pengelolaan Aktiva Passiva Bank,_ UPP AMP YKPN, Jakarta,.

Siamat, Dahlan. 2005. Manajemen Lembaga Keuangan: Kebijakan Moneter dan Perbankan. Jakarta: FE UI.

Sinungan, Muchdarsyah. 2000. Manajemen Dana Bank. Edisi Kedua. Jakarta: PT. Bumi Aksara. 
Susilo, Sri Y,dkk, 2000. Bank dan Lembaga Keuangan Lain, Salemba Empat, Jakarta.

Sutojo, Siswanto, 2008. Menangani Kredit Bermasalah”, PT. Damar Mulia Pustaka, Jakarta.

Undang-Undang Nomor 10 Tahun 1998 Tentang Perubahan Atas Undang-Undang No.7 Tahun 1992. Jakarta: Diperbanyak oleh Bank Indonesia.

Undang-Undang Republik Indonesia Nomor 20 Tahun 2008 tentang Usaha Mikro, Kecil, dan Menengah. 2012. Jakarta: Diperbanyak oleh Kementerian Koperasi dan Usaha Kecil dan Menengah Republik Indonesia.

Warjiyo, Perry. 2004. Bank Indonesia Bank Sentral Republik Indonesia Sebuah Pengantar Pusat Pendidikan dan Studi Kebangsentralan Bank Indonesia, Jakarta.

Widiyanti, Muchtar, Sjahruddin. 2014. Analisis pengaruh CAR, ROA, NPL, BOPO dan DPK terhadap penyaluran kredit UMKM di Indonesia (Studi pada bank umum yang terdaftar di BEI periode 2010-2012). JOM FEKON Vol.1 No.2 Oktober 2014 